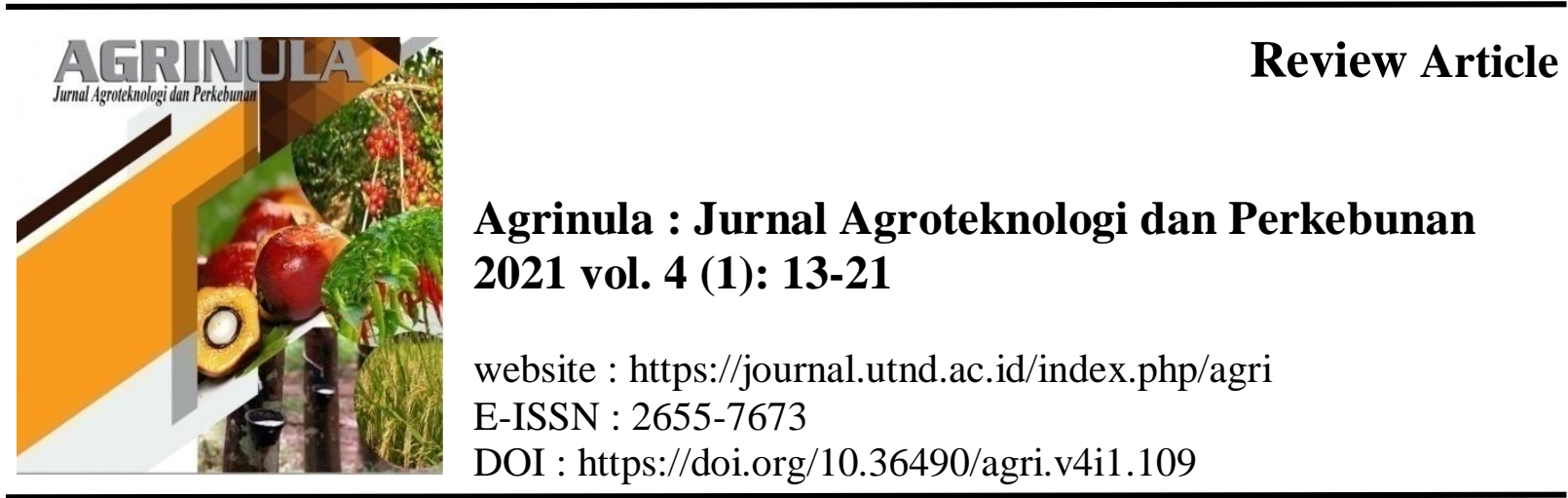

\title{
INFLUENCE OF FOLIAR APPLICATION OF MAGNESIUM ON HORTICULTURAL CROPS: A REVIEW
}

Muhammad Adnan ${ }^{1 *}$, Koko Tampubolon', Fazal ur Rehman ${ }^{3}$, Muhammad Sulaman Saeed ${ }^{4}$, Muhammad Sikander Hayyat ${ }^{1}$, Muhammad Imran $^{1}$, Rohoma Tahir $^{5}$, \& Jitendra Mehta ${ }^{6}$

${ }^{1}$ Department of Agronomy, College of Agriculture, University of Sargodha, Pakistan

${ }^{2}$ Program Study of Agrotechnology, Faculty of Agriculture and Animal Husbandry, Universitas Tjut Nyak Dhien, Medan. Sumatera Utara, Indonesia

${ }^{3}$ Department of Plant Pathology, College of Agriculture, University of Sargodha, Pakistan

${ }^{4}$ Department of Plant Breeding and Genetics, University of Agriculture, Faisalabad, Pakistan

${ }^{5}$ Department of Horticulture, College of Agriculture, University of Sargodha, Pakistan

${ }^{6}$ Research Supervisor, Department of Biotechnology, Career Point University, Rajasthan, India

*Corresponding author: mughal3368@gmail.com

\begin{tabular}{|c|c|}
\hline Article Information & ABSTRACT \\
\hline $\begin{array}{l}\text { Submitted: } \\
\text { January 02, } 2021 \\
\text { Revised: } \\
\text { January 03, } 2021 \\
\text { Accepted: } \\
\text { January 04, } 2021 \\
\text { Published: } \\
\text { January 05, } 2021\end{array}$ & $\begin{array}{l}\text { - Introduction: Magnesium is very important nutrient and } \\
\text { performs a significant part in development and formation } \\
\text { of many sink organs like roots and seeds. Furthermore, } \\
\text { its fertilization significantly affects yield and numerous } \\
\text { physiological mechanisms in different horticulture crop } \\
\text { species. Moreover, its deficiency caused germination and } \\
\text { reduction in horticulture crop stand. Nevertheless, its } \\
\text { adequate concentration by foliar application plays } \\
\text { important role in biochemical and physiological } \\
\text { processes of plants like proteins synthesis, metabolism of } \\
\text { carbohydrates, enzymes activation and energy } \\
\text { transferring. Worldwide, many of our horticulture crops } \\
\text { are facing low yield and quality problem due to fertilizer } \\
\text { application at inadequate rate. The current review } \\
\text { focuses on the impact of foliar applied Mg on some }\end{array}$ \\
\hline
\end{tabular}

Agrinula : Jurnal Agroteknologi dan Perkebunan, 2021 vol. 4 (1): 13-21 


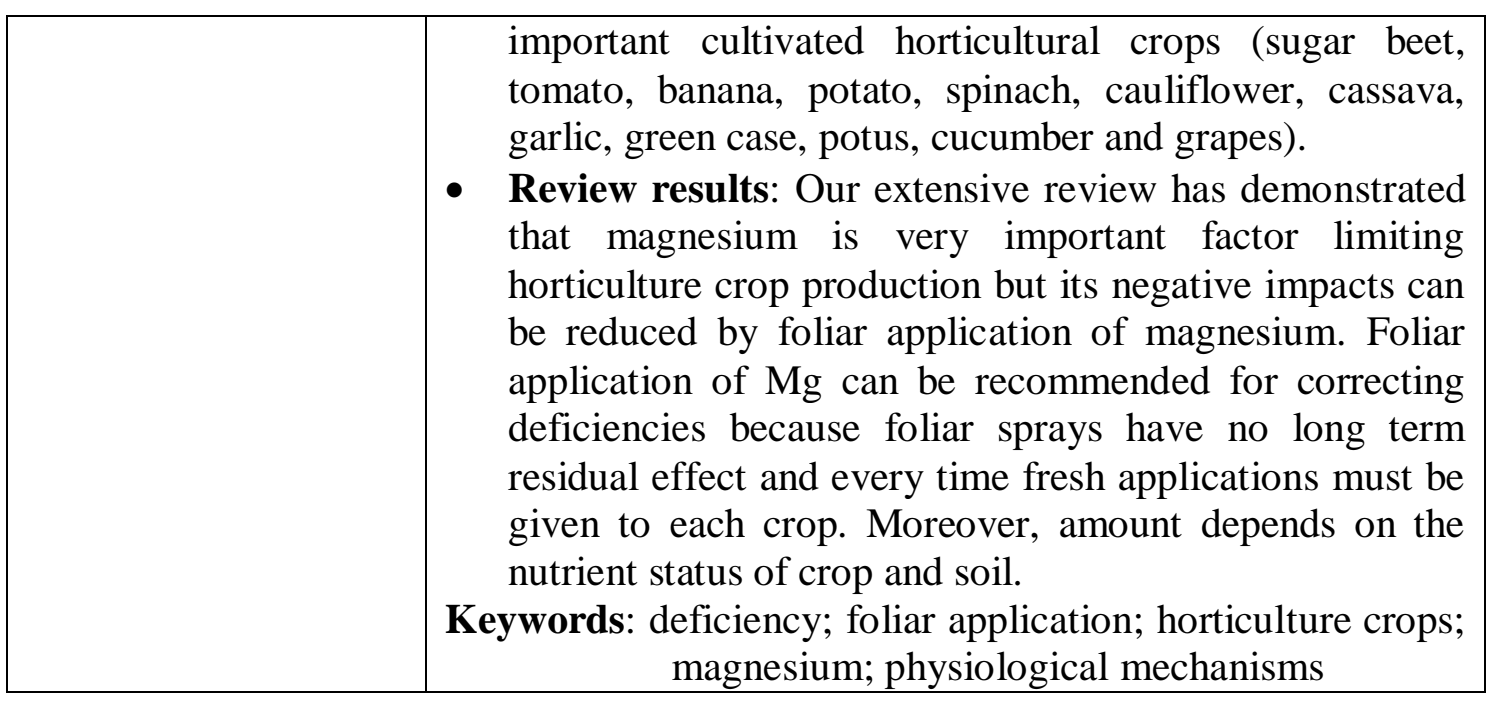

\section{INTRODUCTION}

Food, fiber and fuel are provided by agriculture sector that are the main necessities of a man (Adnan, 2020). Agriculture productions are facing a major challenge to fulfill the requirements of ever growing population (Adnan et al., 2020a), and many poor countries are facing problem of malnutrition (Saeed et al., 2020). Magnesium plays importantfunctionin many physiological functions of plants. Itperforms vital function in the formation and development of seeds and roots i.e. sink organs of plants (Ceylan et al., 2016). The deficiency of Mg mostly occurs where highly acidic weathered soils are present (Wang et al., 2019). Moreover, it has also been reported that the $\mathrm{Mg}$ concentrations in the cereals crops shows a clear decline in last 60 years. It is most possibly due to $\mathrm{Mg}$ dilution associated with increases in the grain yield as well as due to imbalanced fertilization without knowing crop demand for $\mathrm{Mg}$ (Guo et al., 2016). Its fertilization fundamentally influences the crop yield and numerous physiological cycles in different crop species, just as $\mathrm{Mg}$ agronomic efficiencies, under various soil conditions remain the main inquiry to be tended to publically on the grounds that its lack in plants caused lower measures of starch and decrease the germination and seedling formation when looked at Mg satisfactory plants (Wang et al., 2019). Nowadys, many advanced countries are chaning their policies of agriculture to reduce or ban chemical products (Adnan \& Anjum, 2021). The applications of fertilizers can be done to crops by soil and foliar yet foliar application is simple and affordable and environment friendly. (Toor et al., 2020; Adnan et al., 2020b; Bilal et al., 2020; Wasaya et al., 2019). Foliar applied Mg plays an importanct function in physiological and biochemical cycle of plants (Adnan et al., 2020c) for example, compounds initiation for proteins synthesis, Metabolism of starches and energy transfer just as magnesium likewise proceeds as an impetus in oxidation and reduction reaction inside the tissues of plant along with magnesium enhances the resistance against dry spell in plant (Thalooth et al., 1990). The current review focuses on the impact of foliar appliedMg on some important cultivated horticultural crops (sugar beet, tomato, banana, potato, spinach, cauliflower, cassava, garlic, green case, potus, cucumber and grapes). 


\section{REVIEW RESULTS}

Sugar Beet (Beta vulgaris L. ssp. vulgaris)

Kristek, (2000) evaluated the role of Epsom salt on sugar beet. Foliar application of Epsom salt was applied as 5\% w/v solution, 400 litre $^{-1} \mathrm{a}^{-1}$ two times application in ten-day interim of June. The results depicted that great differences in sucrose, yields, Amino-N, Potassium and Sodium status of sugar beet werenoted among years and among three tested areas in all three years of testing and results also recorded that foliar application of Epsom salt increased sucrose concentration by $0.25,0.20$ and $0.26 \%$ at growing periods 1995, 1996 and 1997, respectively. The sugar production was increased in amount of 0.40 ton $\mathrm{ha}^{-1}$ in the third year testing and also enhanced the root quality but decreased Amino- $\mathrm{N}$ content in the $2^{\text {nd }}$ year.

\section{Tomato (Lycopersicon esculentum Mill.)}

Hao \& Papadopoulos, (2003) carried out an experiment in rockwool to test the effect of two levels of calcium $150 \mathrm{mg}$ and $300 \mathrm{mg}$ per litre are combine with four levels of $\mathrm{Mg}$ (110, 80, 50 and $20 \mathrm{mg} \mathrm{litre}^{-1}$ ) on tomato (Lycopersicon esculentum Mill.). Results revealed that high concentration of Calcium (300 mg per litre) improved the yield of fruit but the low level of calcium (150 mg per litre) decreased russeting of fruit and theblossom occurrence. However high level of calcium decreased firmness of fruit but the leaf photosynthesis and fruit size did not decrease. While the leaf chlorosis shows the symptoms at the level of $20 \mathrm{mg}$ per litre of magnesium at the bottom and mid of the leaves after eight weeks of planting. The $50 \%$ of the moderate chlorosis of leaves lost their photosynthetic capacity as well as production of fruit in the delayed period reduced at the magnesium level of $20 \mathrm{mg}$ per litre. The occurrence of blossom end rot enhanced with increasing magnesium level in the premature stage of growth at low level of Calcium while the occurrence of blasoom end rot at high level of Calcium were not affected by magnesium level. However, the firmness of fruit enhanced with enhancing magnesium level with low Calcium. The high levels of calcium and magnesium influenced the firmness of fruit in late period but at the level of magnesium $80 \mathrm{mg}$ per litre in firmness of fruit, the magnesium level was more than $50 \mathrm{mg}$ per litre. While in the mid period russeting of fruit was influenced by treatments, being at the smallest amount of Calcium/Magnesium 300/50 mg per litre. However, the optimal level of Calcium/Magnesium in the fall greenhouse for tomato yield is projected to 300/50-80 $\mathrm{mg}$ per litre and magnesium level started from $50 \mathrm{mg}$ per litre and slowly enhanced to $80 \mathrm{mg}$ per litre towards the last period and also to develop the growth of plant improve the firmness of fruit.

\section{Banana (Musa L.)}

Mostafa et al., (2007) investigated the influence of foliar $\mathrm{Mg}$ application in the form of sulphate and chelate with or without magnesium sulphate on vegetative stage, leaf chlorophyll, mineral, yield and fruit quality of banana plants cultivated under clay loam soil conditions. Results showed that $\mathrm{Mg}$ application have positive impact on 
growth parameters, yield and fruit quality with the application of $100 \mathrm{~g} \mathrm{Mg}$ at chelate form $2 \% \mathrm{MgSO}_{4}$ foliar application.

\section{Potato (Solanum tuberosum L.)}

El-Zohiri \& Asfour, (2009) laid out two field experiments at the experimental farm during two successive fall seasons 2005/2006 and 2006/2007 to tested the effects of potassium, magnesium and calcium and their combination on yield, yield components, chemical constituents and storage ability of potato tuber cv valor. Results showed that foliar appllied potassium sulphate combined with calcium nitrate or with magnesium gave significant effects on number of tubers weight of tubers, yield and yield components. However, maximum number of tuber, weight of tubers per plant, total and relative enhance in yield were obtained by foliar application of potassium sulphate and magnesium sulphate and results also indicated that best number of days for sprouting were recorded in the foliar $\mathrm{Mg}$ sulpate application. weight loss percentage after 90, 60 and 30 days after storage were significantly enhanced with the application of $\mathrm{Mg}$ sulphate alone whereas application of potassium nitrate and magnesium sulphate in first season and potassium sulphate and magnesium sulphate in the $2^{\text {nd }}$ season gave the maximum dry matter after 90 days. Horvat et al., (2010) concluded that foliar applications of three salts and control on various parameters such as the content index of chlorophyll, size of tuber and production of potato grown under water scarce situations. The research was conducted out in greenhouse using the cultivar of 'Courage' throughout the three growing periods (2005, 2006, 2007). Foliar application was applied 5 times throughout vegetation period from the beginning of formation of tuber to the phase of full tuberization. The results depicted that there was no major variation in chlorophyll content index of potato leaf prejudiced by foliar application among water scarce situations and optimal irrigate supply. While, production of tuber was considerably decreased by an aggregate of $15 \%$ beneath water scarce situations. Moreever, the water scarcity showed in a drastically more number of 0-25 mm tuber sizes, but lesser number of 50-75 mm tuber sizes. Foliar spray of magnesium sulphate carried regarding alike production of tuber underneath situations of water scarce and optimal water provide. While In difference, salts and control treatment obtained extensively higher production of tubers beneath optimal water deliver compared to water scarce situations.

\section{Spinach (Spinacia oleracea L.)}

Borowski \& Michalek, (2010) conducted an experiment of pod in a phytotron to findout the impact of foliar applied nutrients on spinach with various $\mathrm{Mg}$ salts with and without $0.5 \% \mathrm{CO}\left(\mathrm{NH}_{2}\right)_{2}$ addition was examined. Magnesium was applied three times, $\mathrm{Mg}\left(\mathrm{NO}_{3}\right)_{2} \times 6 \mathrm{H}_{2} \mathrm{O}, \mathrm{MgSO}_{4} \times 7 \mathrm{H}_{2} \mathrm{O}, \mathrm{C}_{4} \mathrm{H}_{6} \mathrm{O}_{4} \mathrm{Mg}$ x $4 \mathrm{H}_{2} \mathrm{O}, \mathrm{MgCl}_{2}$ x $6 \mathrm{H}_{2} \mathrm{O}$, compared to water as the control treatment. The significant effects indicated that the foliar nutrition of spinach and with inorganic magnesium salts was a well-organized technique for improving the magnesium concentration in plants throughout the growing stage. 
However, the application of a organic metalo complex in the form of $\mathrm{Mg}$ acetate $\left(\mathrm{C}_{4} \mathrm{H}_{6} \mathrm{O}_{4} \mathrm{Mg} \times 4 \mathrm{H}_{2} \mathrm{O}\right)$ at a level of $1.7 \%$, in spite of approximating result on leaf magnesium content, induced phytotoxic effect in the form of necrotic and chlorotic spots on leaves. The inorganic magnesium salts application had a positive result which is more intensive gas exchange of leaf such as transpiration, stomatal conductance, and photosynthesis and an increase in leaf yield. The foliar nutrition of the spinach with $\mathrm{Mg}$ salts ensued in an enhanced leaf protein,carotenoids, proline, chlorophyll and nitrates while a reduction in the vitamin $\mathrm{C}$. The urea addition to magnesium salt solutions enhanced the plant gas exchange rates and the leaf content of protein, chlorophyll, carotenoids, nitrates and proline, but it decreased the content of vitamin $\mathrm{C}$, potassium and magnesium.

\section{Cauliflower (Brassica oleracea var. botrytis)}

Ahmed et al., (2011) studied foliar application of molybdenum and magnesium on the vegetative growth, chemical (\%) and curds production of cauliflower. Foliar $\mathrm{Mg}$ application was carried out four times 20, 40, 60 and 80 days after transplanting at the level of $(15,30$ and $45 \mu \mathrm{g} / 1 \mathrm{Mo})$ and magnesium was applied four times 15, 35, 55 and 75 days at the level of $(0.25,0.50$ and $0.75 \% \mathrm{Mg})$ after transplanting. The data was recorded and results indicated that 30 and $45 \mu / 1$ Mo enhanced the vegetative growth, curds production and chemical composition of leaves and curds similarly 0.50 and $0.75 \%$ foliar application of $\mathrm{Mg}$ improved the fresh weight, plant height, fresh weight of leaves, dry weight of leaves, total production of curds and chemical composition of curds and leaves. Biswas et al., (2013) stated that three magnesium sulphate levels ( 0 , $1.5,3.0 \mathrm{~g} / \mathrm{m}^{2}$ ) were applied on paddy crop, flowers and vegetables during February to May in 2013. Results indicated that the level $3.0 \mathrm{~g} / \mathrm{m}^{2}$ of $\mathrm{MgSO}_{4}$ enhanced the growth and produced highest production of paddy and also positive effect of qualitative and quantitative yield of sunflower, vegetables, and rose.

\section{Cassava (Manihot esculenta Crantz)}

Panitnok et al., (2013) observed that the Micro nutrient application is an essential for adding efficiency of cassava cultivar (Manihot esculenta Crantz) production. The three cassava cultivars (KU 50, HB 60 and HB 80) were grown in coarse-loamy and sandy loam soil with low organic matter at Research Station of Thailand, to assess the combination effects of zinc, sulphur and Magnesium foliar spray management on production and cassava quality. There were five main plots (T1) non foliar fertilization, (T2) foliar application of $\mathrm{Zn}+\mathrm{Mg}+\mathrm{S} @ 10 \mathrm{cc} / 20$ liters of water, $30 \mathrm{cc} / 20$ liters of water and $60 \mathrm{~g} / 20$ liters of ton per hector water at 2 and 3 month after planting (2 times/month), (T3) foliar application of $\mathrm{Zn}+\mathrm{Mg} @ 10 \mathrm{cc} / 20$ liters of water and $30 \mathrm{cc} / 20$ liters of water at 2 and 3 month after planting (2 times/month), (T4) foliar application of Zn+S @ 10 cc/20 liters of water and $60 \mathrm{~g} / 20$ liters of water at 2 and 3 month after planting (2 times/month) and (T5) foliar application of Mg+S @ $30 \mathrm{cc} / 20$ liters of water and $60 \mathrm{~g} / 20$ liters of water at 2 and 3 month after planting (2 times/month) and three 
cassava cultivars in sub plots (V1) KU 50, (V2) HB 60 and (V3) HB 80. The results exemplified that the treatment with different rates of zinc, magnesium and sulphur gave difference in fresh stem weight, fresh rhizome weight, fresh root weight and root starch content, but the foliar application with $\mathrm{Zn}+\mathrm{Mg}+\mathrm{S}$ gave the highest on its while KU 50 cultivar gave the better result on fresh stem weight and fresh rhizome weight, HB 60 cultivar inclined to give greater fresh root yield $\left(11.90 \mathrm{t} \mathrm{rai}^{-1}\right.$ or $\left.74.38 \mathrm{t} \mathrm{ha}^{-1}\right)$ and fresh root weight (370.10 g/root). However, HB 80 cultivar inclined to give higher root starch content $(27.16 \%)$ and root number (13.81 root/plant). The maximum fresh root yield (15.77 t rai-1 or $\left.98.56 \mathrm{t} \mathrm{ha}^{-1}\right)$ and fresh root weight $(442.45 \mathrm{~g} /$ root $)$ was obtained from $\mathrm{Zn}+\mathrm{Mg}$ treatment sprayed on HB 60 cultivar, however, the HB 80 cultivar with foliar application of $\mathrm{Zn}+\mathrm{Mg}+\mathrm{S}$ gave the highest root starch content of cassava by $29.33 \%$.

\section{Garlic (Allium sativum L.)}

Al-Barzinji \& Naif, (2014) evaluated that foliar application of different magnesium salts $\left(\mathrm{MgSO}_{4} .7 \mathrm{H}_{2} \mathrm{O}, \mathrm{Mg}\left(\mathrm{NO}_{3}\right)_{2} \cdot 6 \mathrm{H}_{2} \mathrm{O}, \mathrm{MgCl}_{2} .6 \mathrm{H}_{2} \mathrm{O}\right.$ and control) on garlic (Allium sativum L.). Positive and good vegetative growth of garlic was produced by magnesium salts. Highest number of leaves was produced by $\mathrm{MgCl}_{2}$; highest dry weight of shoots was enhanced by $\mathrm{Mg}\left(\mathrm{NO}_{3}\right)_{2}$ but lowest plant height was produced by $\mathrm{MgSO}_{4}$. The foliar application of $\mathrm{MgSO}_{4}$ and $\mathrm{Mg}\left(\mathrm{NO}_{3}\right)_{2}$ enhanced the yield components like head diameter, head weight, bulbs production and cloves number per head and also enhanced the production and yield quality of garlic.

\section{Green Pod (Pisum sativum L.)}

Howladar et al., (2014) stated that the results of soil treatment with phosphorien containing phosphate dissolving bacteria (PDB) and $\mathrm{Mg}$ foliar spray at the concentrations of $0,0.5$ and $1 \mathrm{mM}$ on growth, green pod and production, and chemical components of Pisum sativum L. cultivated on a sandy calcareous soil were examined. The effects showed that phosphate dissolving bacteria and magnesium considerably enhanced per plant length of shoot, number of branches, total leaf area and canopy dry weight per plant, leaf contents of pigments, soluble sugars, free proline, $\mathrm{N}, \mathrm{P}, \mathrm{K}, \mathrm{Mg}$ and $\mathrm{Ca}$ and also determined that phosphate dissolving bacteria and magnesium have good effects on Pisum sativum L. crop cultivated in sandy calcareous soil and can enhanced the green pod and seed yields.

\section{Potus Plant (Epipremnum aureum)}

Metwally et al., (2015) laid out an experiment during two growing seasons 2012 and 2013 at the laboratory of National Research Centre, Egypt to determine the effect of potus plants (Epipremnum aureum) watered by waste water of attractive fish basins liquefy with tap water (DWOFB) at the levels 100\% DWOFB, 75\% DWOFB $+25 \%$ Tap water and 50\% DWOFB + 50\% Tap water) and combined with Epsom salt as foliar application level (EFAL) at the level EFAL1 (25 ppm) and EFAL (50 ppm). The results showed that the crop watered with total fish waste (100\% fish) 
single or combined with magnesium $50 \mathrm{ppm}$ achieved the maximum growth components, the maximum carbohydrate percentage enhanced in photosynthetic pigments. The foliar spray of magnesium $50 \mathrm{ppm}$ had progressive result on growth parameters and drastically enhances in photosynthetic pigments. The crop watered with fish water waste $75 \%$ followed by $50 \%$ had the second and the third largest average growth parameters and chemical constituents respectively.

\section{Cucumber (Cucumis sativus L.)}

Azarmi et al., (2015) evaluated that five different $\mathrm{Mg}$ concentration levels (0, 1, 2, 3 and $4 \mathrm{mM}$ ) in the solution form were applied on cucumber plant in hydroponic culture under low 50\% and optimum 100\% light intensity. He demonstrated that the concentration of $\mathrm{Mg}(3 \mathrm{mM})$ in the form of nutrient solution in hydroponics with the optimum light intensity enhanced the growth and fruit quality of cucumber plant, but decreases the growth and fruit quality with the decreases of light intensity and also reduced the growth and fruit quality with the increased of $\mathrm{Mg}$ level (4 mM). $\mathrm{Mg}$ concentration of $1 \mathrm{mM}$ enhanced the fruit firmness with the increasing light intensity.

\section{Grapes (Vitis vinifera)}

Zlamalova et al., (2015) carried out three-year field experiment (2011-2013) to study the effects foliar application of magnesium sulphate and potassium sulphate both separately $3.86 \mathrm{~kg} \mathrm{Mg}$ per hectare or $12.44 \mathrm{~kg} \mathrm{~K}$ per hectare and in combination $1.93 \mathrm{~kg}$ $\mathrm{Mg}$ per hectare plus $6.22 \mathrm{~kg} \mathrm{~K}$ per hectare on yield of grapes of cv. Zweigelt and some qualitative parameters of the grapes. The average 3-year results the grape yields were obtained by $11.2 \%$ magnesium sulphate, $13.9 \%$ potassium suphate and $6.6 \%$ magnesium sulphate plus potassium sulphate considerably more than the control. The sugar content of grapes like sum of glucose and fructose was lesser in all the fertilized treatments than in the control. The fertilizer application had no effect on the $\mathrm{pH}$ of must (juice) and ranged between 3.02 and 3.25. Results showed that it is obvious that separate foliar applications of magnesium and potassium have a good effect, in exacting in that they enhance grape yield.

\section{CONCLUSION}

Our extensive review has demonstrated that magnesium is very important factor limiting horticulture crop production but its negative impacts can be reduced by foliar application of magnesium. Foliar application of $\mathrm{Mg}$ can be recommended for correcting deficiencies because foliar sprays have no long term residual effect and every time fresh applications must be applied to each crop. Moreover, amount depends on the nutrient status of crop and soil.

\section{REFERENCES}

Adnan, M. (2020). Remote sensing an innovative way to improve crop production: A review. Current Trends in Engineering Science, 1(1), 1003. 
Adnan, M., \& Anjum, M. Z. (2021). Back to past; organic agriculture. Acta Scientific Agriculture, 5(2), 01-02.

Adnan, M., Abbas, B., Asif, M., Hayyat, M. S., Ali, R., Khan, B. H., Khan, M. A. B., Toor, M. D., \& Khalid, M. (2020b). Role of micro nutrients bio-fortification in agriculture: A review. International Journal of Environmental Sciences \& Natural Resources, 24(4), 209-213. http://dx.doi.org/10.19080/IJESNR.2020.24.556141.

Adnan, M., Asif, M., Bilal, H. M., Rehman, B., Adnan, M., Ahmad, T., Rehman, H. A., \& Anjum, M. Z. (2020a). Organic and inorganic fertilizer; integral part for crop production. EC Agriculture, 6(3), 01-07. Source: https://www.ecronicon.com/ecag/ECAG-06-00266.php.

Adnan, M., Hayyat, M. S., Imran, M., ur Rehman, F., Saeed, M. S., Mehta, J., \& Tampubolon, K. (2020c). Impact of foliar application of magnesium fertilizer on agronomic crops: A review. Indian Journal of Pure and Applied Biosciences, 8(6), 281-288. http://dx.doi.org/10.18782/2582-2845.8465.

Ahmed, M. E., Elzaawely, A. A., \& El-Sawy, M. B. (2011). Effect of the foliar spraying with molybdenum and magnesium on vegetative growth and curd yields in cauliflower (Brassica oleraceae var. botrytis L.). World Journal of Agricultural Sciences, 7(2), 149-156.

Al-Barzinji, I. M., \& Naif, A. S. (2014). Effect of magnesium salts on growth and production of garlic (Allium sativum L.). The Scientific Journal of Koya University, 2(1), 1-5. http://dx.doi.org/10.14500/aro.10038.

Azarmi, R., Tabatabaei, S. J., \& Chaparzadeh, N. (2015). Effect of magnesium on growth, fruit quality and sugar content in cucumber under various light intensities. International Journal of Biology, Pharmacy and Allied Sciences, 4(9): 5915-5932.

Bilal, H. H., Tahir, R., Adnan, M., Ali, S. M., Islam, H., Umer, M. S, Mir, F. A., Ahmad, R. I., \& Iftikhar, M. (2020). Does foliar application of macro and micronutrients have any impact on roses production? A review. Annals of $\begin{array}{llll}\text { Reviews } \quad \text { and } & \text { 6(1), }\end{array}$ http://dx.doi.org/10.19080/ARR.2020.05.555677.

Biswas, B., Dey, D., Pal, S., \& Kole, N. (2013). Integrative effect of magnesium sulphate on the growth of flowers and grain yield of paddy: a chemist's perspective. Rasyan Journal of Chemistry, 6(4), 300-302.

Borowski, E., \& Michalek, S. (2010). The effect of foliar nutrition of spinach (Spinacia oleracea L.) with magnesium salts and urea on gas exchange, leaf yield and quality. Acta Agrobotanica, 63(1), 77-85. https://doi.org/10.5586/aa.2010.009.

Ceylan, Y., Kutman, U. B., Mengutay, M., \& Cakmak, I. (2016). Magnesium applications to growth medium and foliage affect the starch distribution, increase the grain size and improve the seed germination in wheat. Plant Soil, 406(1-2), 145-156. https://doi.org/10.1007/s11104-016-2871-8.

El-Zohiri, S. S. M., \& Asfour, H. E. (2009). Effects of foliar sprays of potassium, magnesium and calcium on yield, quality and storageability of potato. In The Fifth Inter. Conf. of Suastain Agric., Develop. Faculty of Agriculture - Fayoum University, (pp. 21-23).

Guo, W., Nazim, H., Liang, Z., \& Yang, D. (2016). Magnesium deficiency in plants: an urgent problem. The Crop Journal 4(2), 83-91. https://doi.org/10.1016/j.cj.2015.11.003. 
Hao, X. \& Papadopoulos, A. P. (2003). Effects of calcium and magnesium on growth, fruit yield and quality in a fall greenhouse tomato crop grown on rockwool. Canadian Journal of Plant Science, 83(4), 903-912. https://doi.org/10.4141/P02140.

Horvat, T., Poljak, M., Lazarević, B., Karažija, T., \& Svečnjak, Z. (2010). Effect of foliar fertilizers on yield and yield structure of potato tuber grown under water stress conditions. Effect of foliar fertilizers on chlorophyll content index and yield of potato crop grown under water stress conditions. Növénytermelés, 59 , 215-218.

Howladar, S. M., Osman, A. S., Rady, M. M., \& Al-Zahrani, H. S. (2014). Magnesium foliar application and phosphorien soil inoculation positively affect Pisum sativum L. plants grown on sandy calcareous soil. International Journal of Agricultural and Biosystems Engineering, 8(5): 436-440. https://doi.org/10.5281/zenodo.1092231.

Kristek, A., Kovačević, V., \& Antunović, M. (2000). Response of sugar beet to foliar magnesium fertilization with epsom salts. Rostlinná Výroba, 46(4), 147-152.

Metwally, S. A., Abdelraouf, R. E., \& Abou-Leila, B. H. (2015). Response of potus plants (Epipremnum aureum) to irrigation with drainage water of ornamental fish basins and magnesium sulphate as foliar fertilizer. American Journal of Life Sciences, 3(4), 306-310. http://dx.doi.org/10.11648/j.ajls.20150304.18.

Mostafa, E. A. M., Sakeg, M. M. S., \& El-Migeed Abd MM, M. (2007). Response of banana plants to soil and foliar applications of magnesium. American-Eurasian Journal of Agricultural and Environmental Sciences, 2(2), 141-146.

Panitnok, K., Chaisri, S., Sarobol, E. D., Ngamprasitthi, S., Chaisri, P., Changlek, P., \& Thongluang, P. (2013). The combination effects of zinc, magnesium, sulphur foliar fertilizer management on cassava growth and yield grown on Map Bon, coarse-loamy variant soil. Procedia-Social and Behavioral Sciences, 91, 288293. https://doi.org/10.1016/j.sbspro.2013.08.425.

Saeed, M. S., Saeed, A., \& Adnan, M., (2020). Production and utilization of single cell proteins-an overview. Current Research in Agriculture and Farming, 1(4), 9-12. http://dx.doi.org/10.18782/2582-7146.117.

Thalooth, A. T., El-Zeiny, H. A., \& Saad, A. O. M. (1990). Application of potassium fertilizer for increasing salt tolerance of broad bean (Vicia faba L.). Bulletin of Egyptian Society for Physiological Sciences 10, 181-193.

Toor, M. D., Adnan, M., Javed, M. S., Habibah, U., Arshad, A., Din, M. M., \& Ahmad, R. (2020). Foliar application of Zn: Best way to mitigate drought stress in plants; A review. International Journal of Applied Research, 6(8), 16-20.

Wang, Z., Hassan, M. U., Nadeem, F., Wu, L., Zhang, F., \& Li, X. (2019). Magnesium Fertilization improves crop yield in most production systems: a meta-analysis. Frontiers in Plant Science. 10, 1727. https://doi.org/10.3389/fpls.2019.01727.

Wasaya, A., Affan, M., Yasir, T. A., Sheikh, G. R., Aziz, A., Baloach, A. W, Nawaz, F.,\& Adnan, M. (2019). Growth and economic return of maize (Zea mays L.) with foliar application of potassium sulphate under rainfed conditions. Journal of Environmental and Agriculture, 4(1), 268-374.

Zlámalová, T., Elbl, J., Baroň, M., Bělíková, H., Lampíŕ, L., Hlušek, J., \& Lošák, T. (2015). Using foliar applications of magnesium and potassium to improve yields and some qualitative parameters of vine grapes (Vitis vinifera L.). Plant, Soil and Environment, 61(10), 451-457. https://doi.org/10.17221/437/2015-PSE. 